\title{
Discovery Learning dengan Memanfaatkan Kemasan Kudapan: Analisis Keterampilan Menulis Teks Persuasi
}

\author{
Bella Ika Novillia Widyaning Putri, Sutrimah, Cahyo Hasanudin \\ ${ }^{1}$ Pendidikan Bahasa dan Sastra Indonesia, IKIP PGRI Bojonegoro \\ Email: ikabella027@gmail.com \\ ${ }^{2}$ Pendidikan Bahasa dan Sastra Indonesia, IKIP PGRI Bojonegoro \\ Email: sutrimah@yahoo.com \\ ${ }^{3}$ Pendidikan Bahasa dan Sastra Indonesia, IKIP PGRI Bojonegoro \\ Email: cahyohasanudin@ikippgribojonegoro.ac.id
}

\begin{abstract}
This studi aimed to investigate the form of persuasive text written by eight grade students of MTs Darussalam Deru, Sumberrejo, Indonesia in discovery learning. This study was qualitative research in form of case study with 28 students as the research subjects. Four students were chosen to be interviewed because the persuasive text was in line with the indicators. Techniques of collecting data were observation, test method, interview, and documentation. The data was validated by using triangulations of data sources and method. Technique in analysing data was content analysis that was started from 1) data reduction, 2) data presentation, 3) drawing conclusion and verification. The results of this study showed that the structure of persuasive text written by the eight grade students of MTs Darussalam Deru, Sumberrejo, Indonesia had been referred to the structure that was well appropriated to the theory of Kosasih. The conclusion of this study showed that the discovery learning by using a wrapped media was appropriate to be implemented. It could train the students in improving their cognitive skills and curiosities.
\end{abstract}

Keywords: Persuasive Text; Discovery Learning; Wrapped Media

Abstrak. Penelitian ini bertujuan untuk mengetahui bentuk teks persuasi yang ditulis oleh siswa kelas VIII MTs. Darussalam Deru, Sumberrejo, Bojonegoro, Indonesia pada pembelajaran discovery learning. Penelitian ini adalah penelitian kualitatif dengan menggunakan pendekatan studi kasus dengan jumlah subjek 28 siswa. Dari 28 siswa kemudian peneliti mengambil 4 siswa untuk diwawancarai dengan alasan teks persuasi sesuai dengan indikator. Teknik pengumpulan data menggunakan observasi, metode tes, wawancara, dan dokumentasi. Data divalidasi dengan menggunakan triangulasi sumber data dan triangulasi metode. Teknik analisis data menggunakan metode content analysis yang dimulai dari 1) reduksi data, 2) penyajian data, 3) penarikan simpulan dan verifikasi. Hasil penelitian menunjukkan bahwa struktur teks persuasi yang ditulis oleh siswa kelas VIII MTs. Darussalam Deru, Sumberrejo, Bojonegoro, Indonesia sudah mengacu pada struktur teks persuasi sesuai dengan teori Kosasih dengan baik. Simpulan pada penelitian ini adalah pembelajaran discovery learning berbantuan media kemasan kudapan sangat tepat diterapkan pada pembelajaran. Pembelajaran discovery learning berbantuan media kemasan kudapan dapat melatih siswa dalam meningkatkan keterampilan kognitif dan mengembangkan rasa ingin tahu siswa.

Kata kunci : Teks Persuasi; Discovery learning; Kemasan Kudapan 


\section{PENDAHULUAN}

Mata pelajaran bahasa Indonesia sudah diajarkan sedini mungkin dengan berbagai standar kompetensi dan kompetensi dasar yang berbeda, mulai dari sekolah dasar sampai perguruan tinggi matapelajaran bahasa Indonesia selalu mengisi dan menjadi matapelajaran yang selalu ada dijenjang pendidikan, apapun kurikulumnya bahasa Indonesia juga selalu mengisi daftar matapelajaran pada jenjang pendidikan tersebut Hasanudin (2016).

Salah satu materi utama dalam matapelajaran bahasa Indonesia berkaitan dengan empat keterampilan berbahasa. Keterampilan berbahasa menurut Idris, Thahar \& Juita, (2014) merupakan hal yang harus dikuasai oleh siswa. Keterampilan berbahasa bersifat terpadu. Artinya, empat keterampilan ini saling berkaitan antara keterampilan menyimak, berbicara, membaca dan menulis.

Menulis merupakan rangkaian proses berfikir yang berkaitan dengan kegiatan penalaran (Nurfaedah, 2019). Sedangkan menurut Tarigan (2008) menulis merupakan suatu kegiatan yang produktif dan ekspresif. Hal ini senada dengan pendapat Hidayah, Darmuki \& Hasanudin (2019) yang mengemukakan bahwa menulis merupakan suatu aktivitas penting pada pembelajaran, sehingga dengan menulis kita dapat menghasilkan karya dan menemukan ide-ide baru. Di dalam pembelajaran buku bahasa Indonesia kelas VIII terdapat materi pembelajaran diantaranya, 1) teks berita, 2) teks iklan, slogan atau poster, 3) teks eksposisi, 4) teks puisi, 5) teks eksplanasi, 6) teks drama, dan 7) teks persuasi.

Pada kurikulum 2013 pembelajaran menulis teks persuasi diajarkan pada kelas VIII SMP/MTs. semester genap. Pada kompetensi dasar 4.14 yaitu menyajikan teks persuasi (saran, ajakan, arahan, dan pertimbangan) secara tulis dan lisan dengan memperhatikan struktur, kebahasaan, atau aspek lisan.

Teks persuasi merupakan sebuah teks atau tulisan yang di dalamnya mengandung unsur ajakan untuk membujuk atau membuat pembaca lebih percaya dengan apa yang disampaikan (Mardhiyah, 2019). Pembelajaran teks persuasi dibutuhkan dalam pemahaman seorang siswa, hal ini dikarenakan siswa lebih cenderung merasionalkan pemikirannya sehingga dibutuhkanlah kepercayaan dalam pemahaman siswa tersebut. Teks persuasi sendiri memiliki 5 kaidah kebahasaan yaitu 1) kata ajakan dan bujukan, 2) kata kerja imperatif, 3) kata teknis atau istilah, 4) kata kerja mental dan 5) konjungsi argumentatif (Yandis, Pujilestari \& Wuryani 2019).

Menurut Nurmalasari (2020) menulis teks persuasi merupakan salah satu keterampilan berbahasa yang harus dikuasai, namun terdapat beberapa masalah yang menghambat siswa untuk menulis teks persuasi. Kesalahan-kesalahan dalam menulis teks persuasi di antaranya 1) siswa kurang tepat dalam menggunakan diksi, 2) siswa kurang terampil dalam menyusun kalimat yang efektif, 3) siswa kurang jelas dalam menyampaikan ide, 4) siswa kurang tepat dalam penggunaan ejaan maupun tanda baca, 5) siswa kurang terampil dalam menyusun kepaduan dan kesesuaian menyusun paragraf. Sementara itu hasil observasi dan wawancara menunjukkan bahwa siswa masih kesulitan dalam pembelajaran menulis teks persuasi.

Berdasarkan permasalahan yang dialami siswa dalam pembelajaran menulis teks persuasi. Guru harus dapat menciptakan metode pembelajaran yang inovatif. Salah satu metode pembelajaran yang dapat diterapkan dalam proses pembelajaran menulis teks persuasi yaitu metode discovery learning.

Metode discovery learning adalah kegiatan pembelajaran yang diatur sedemikian rupa sehingga anak memperoleh pengetahuan yang belum diketahuinya itu tidak melalui pemberitahuan sebagian atau seluruhnya ditemukan sendiri (Fauzi, Zainuddin \& Atok 2017). Simon dalam Retnowati, dkk. (2018) mengatakan pengetahuan memiliki peran dalam pembentukan perilaku.

Metode discovery learning adalah kegiatan pembelajaran yang dilakukan secara maksimal atau seluruh kemampuan siswa untuk mencari dan menemukan sesuatu secara sistematis, kritis, logis, analitis sehingga mereka dapat merumuskanya sendiri (Fathur, Rohim, Susanto \& Ellianawati, 2012). Metode discovery learning adalah cara belajar yang di dalamnya tidak disajikan sebuah konsep dalam bentuk jadi, namun siswa dituntut untuk menemukan konsep dengan cara belajarnya sendiri (Muhamad, 2016). 
Menurut Putrayasa, Syahruddin \& Margunayasa (2014) kelebihan metode discovery learning yaitu: 1) menjadikan siswa lebih mandiri dalam belajar, 2) memberikan kesempatan kepada siswa untuk mengetahui sumber pengetahuan, 3) mampu menggali kreativitas siswa. Hal tersebut senada dengan Mubarok \& Sulistyo (2014) yang menyatakan bahwa kelebihan pembelajaran discovery learning yaitu: 1) hasilnya lebih baik dari cara belajar yang lain, 2) lebih mudah dipahami, 3) dapat dimanfaatkan dalam bidang studi dan diterapkan dalam kehidupan sehari-hari, 4) untuk meningkatkan kemampuan siswa berfikir dengan baik. Kelebihan dari model discovery learning yaitu: 1) siswa mempunyai rasa ingin tahu, 2) memotivasi siswa untuk terus berfikir hingga menemukan jawaban (menurut Slavin dalam Permana, Pujiastuti, 2017) Namun di dalam metode discovery learning juga terdapat kelemahan.

Kelemahan metode discovery learning yaitu: 1) guru merasa gagal mendeteksi masalah, 2) menyita pekerjaann guru, 3) tidak semua siswa mampu melakukan penemuan (Qodariyah \& Hendriana, 2015). Sedangkan menurut Fitri \& Derlina, (2015) kelemahan metode discovery learning yaitu: 1) dapat menimbulkan asumsi bahwa ada kesiapan pikiran belajar untuk siswa, 2) pada siswa yang kurang pandai, akan mengalami kesulitan untuk berpikir, 3) metode ini tidak maksimal untuk mengajar siswa yang banyak, karena butuh waktu yang lama untuk membantu mereka menemukan teori.

Berpijak pada kelemahan yang ada pada metode pembelajaran discovery learning inilah, maka peneliti ingin mengkolaborasi metode pembelajaran discovery learning dengan sebuah media. Media menurut Hasanudin dalam Mayasari, Hasanudin, \& Fitrianingsih (2020) adalah segala sesuatu yang dapat digunakan untuk menyalurkan pesan dari pengirim ke penerima sehingga dapat merangsang pikiran, perasaan, perhatian, dan minat siswa sedemikan rupa, sehingga proses belajar terjadi.

Media yang dapat merangsang pikiran siswa dalam pembelajaran discovery learning untuk mengoptimalkan kemampuan menulis teks persuasi adalah menggunakan media kemasan kudapan. Kemasan adalah strategi yang dipakai oleh perusahaan untuk memperlihatkan produk agar lebih menarik dari segi bentuk, warna, sehingga produk dapat terjaga kualitasnya (Susetyarsi, 2012). Sekarang ini kemasan sudah berfungsi sebagai media komunikasi, dengan kata lain kemasan kudapan bersifat persuatif atau mengandung unsur ajakan (Muhktar \& Nurif, 2015).

Adanya media kemasan kudapan ini agar siswa mudah menemukan teks persuasi yang ada di dalam kemasan kudapan. Karena pada pembelajaran teks persuasi dimulai dari guru yang memberikan kemasan kudapan kepada siswa sehingga siswa dapat mudah menemukan teks persuasi yang ada di dalam kemasan kudapan tersebut. Adapun kemasan kudapan yang digunakan pada penelitian ini adalah sebagai berikut.
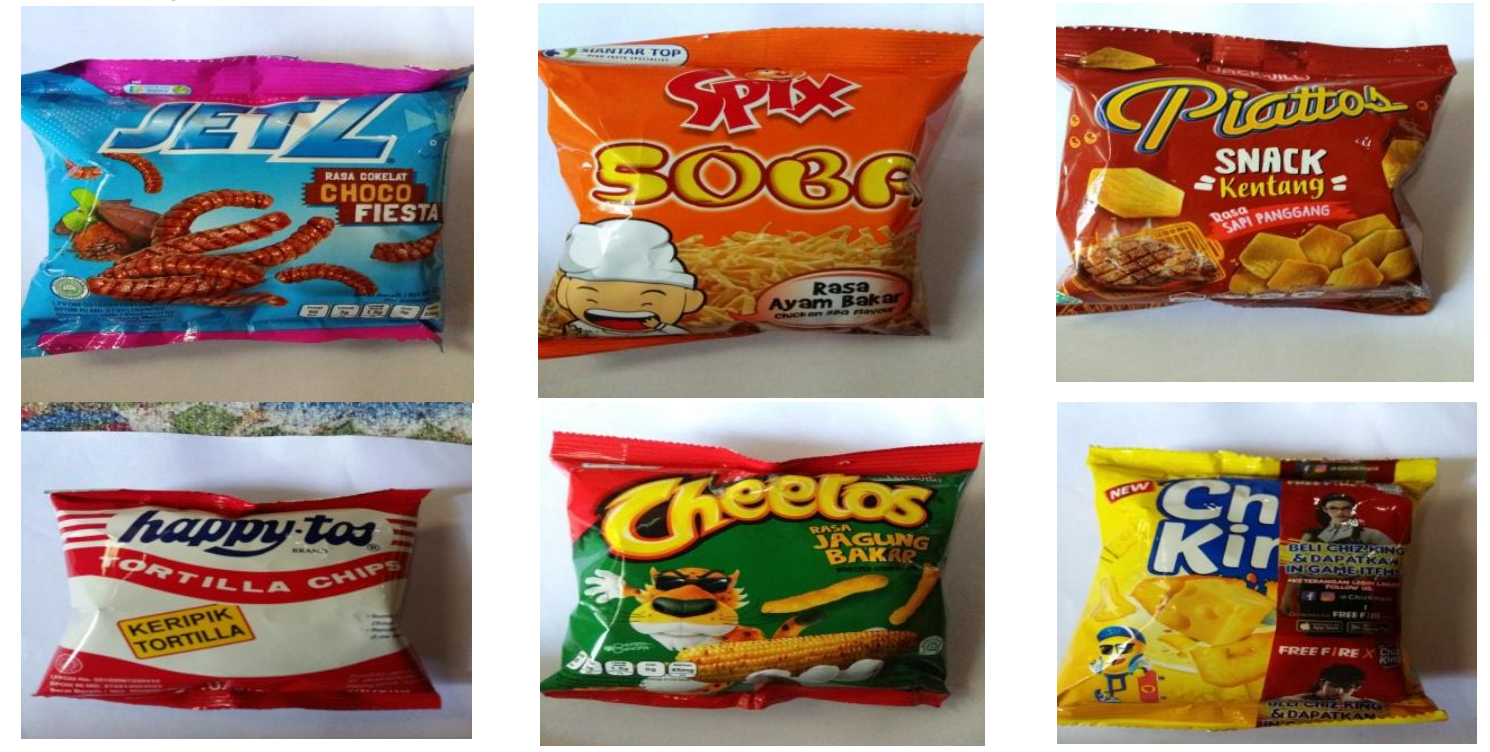

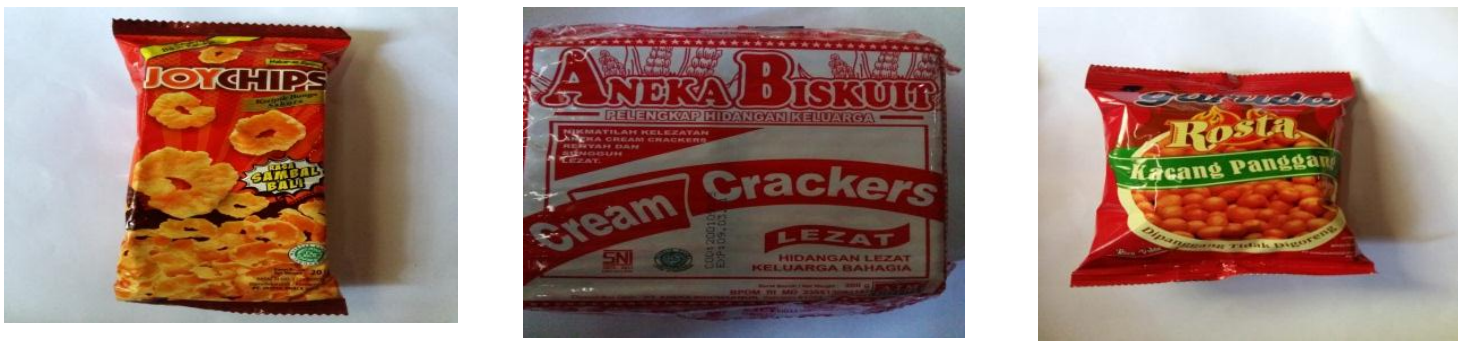

Gambar 1. Macam-macam kemasan kudapan sebagai media pembelajaran

Pada penelitian yang dilakukan oleh Amalia, Syahrul \& Arief (2018) mengenai pengaruh model pembelajaran discovery learning berbantuan media audiovisual terdapat pengaruh yang signifikan dalam keterampilan menulis teks eksposisi. Sedangkan pada penelitian yang dilakukan oleh Cahyaningsih \& Wikanengsih, (2019) mengenai kemampuan menulis teks persuasi maka bisa disimpulkan bahwa penggunaan metode STAD dapat meningkatkan keterampilan menulis siswa pada materi teks persuasi. Penelitian yang dilakukan oleh Sari \& Rachmawati (2019) mengenai analisis pengaruh parsial, kemasan, warna, rasa dan pengetahuan gizi terhadap keputusan pembelian produk makanan pada siswa SD terdapat pengaruh yang signifikan antara kemasan dam gizi terhadap keputusan pembelian.

Proses pembelajaran metode discovery learning berbantuan media kemasan kudapan jika diterapkan dalam pembelajaran teks persuasi ini sangat membantu siswa dalam keterampilan menulis teks persuasi. Siswa dapat dengan mudah menemukan teks persuasi yang ada di kemasan kudapan dan siswa mampu menumbuhkan kreativitas dalam menulis teks persuasi tersebut.

\section{METODE PENELITIAN}

Penelitian ini adalah penelitian deskriptif kualitatif. Penelitian kualitatif adalah metode penelitian yang berdasarkan pada aliran postpositivisme, yang digunakan untuk meneliti pada kondisi obyek alamiah (sebagai lawanya adalah eksperimen) dimana peneliti adalah sebagai alat kunci, teknik pengumpulan data yang dilakukan secara gabungan, analisis data yang bersifat induktif/kualitatif, dan hasil penelitian kualitatif lebih menekankan makna dari suatu kesimpulan (Sugiyono, 2015). Data yang diperoleh pada penelitian ini adalah bagaimana bentuk teks persuasi (pengenalan isu, rangkaian argument, pernyataan ajakan, penegasan kembali) yang ditulis siswa kelas VIII MTs. Darussalaam Deru, Sumberrejo, Bojonegoro, Indonesia ketika diajar dengan menggunakan pembelajaran discovery learning.

1. Subjek Penelitian

Subjek penelitian ini berjumlah 28 siswa. Dari 28 siswa diambil lagi 4 siswa untuk diwawancarai dengan alasan kemampuan menulis teks persuasi sesuai dengan indikator.

2. Sumber Data

Sumber data adalah subjek dari mana data didapatkan (Arikunto, 2006). Pada penelitian ini sumber data yang dimaksud adalah siswa kelas VIII MTs Darussalam Deru Kecamatan Sumberjo. Data yang diperoleh dari siswa berupa hasil tes mengenail keterapilan menulis teks persuasi dan wawancara dengan siswa.

3. Prosedur Pengumpulan Data

Prosedur pengumpulan data pada penelitian ini dilakukan dengan pemberian observasi, metode tes, metode wawancara, dan dokumentasi.

\section{a. Observasi}

Observasi adalah cara atau metode menghimpun keterangan atau data yang dilakukan dengan mengadakan pengamatan dan pecatatan secara sistematis terhadap fenomena yang sedang dijadikan sasaran pengamatan (mania, 2008). 


\section{b. Metode Tes}

Metode tes adalah alat pengumpulan data untuk mengukur kemampuan siswa pada aspek kognitif mengenai mata pelajaran (Widodo \& Widayanti, 2013). Tes menulis digunakan untuk mengetahui keterampilan menulis teks persuasi siswa kelas VIII MTs. Darussalam Deru Kecamatan Sumberrejo. Tes menulis dilakukan oleh siswa sesuai dengan indikator. Adapun langkah-langkah yang dilakukan oleh peneliti dalam penghimpauan data dengan tes adalah a) peneliti yaitu menyiapkan soal tes, b) peneliti membagi soal tes kepada siswa, c) peneliti mengawasi kerja siswa dalam mengerjakan soal tes, d) peneliti mengumpulkan hasil tes, e) peneliti mengoreksi hasil tes, $\mathrm{f}$ ) peneliti menganalis hasil tes siswa.

c. Metode Wawancara

Pada penelitian ini wawancara dilakukan oleh peneliti secara tak berstruktur. Wawancara tak berstruktur dipilih dalam penelitian ini, sebab wawancara tak berstruktur pada umumnya sinkron dengan pribadi siswa, lebih independen sehingga subjek tidak merasa bosan dalam berbagi suatu persoalan. Langkah-langkah yang peneliti lakukan dalam mengumpulkan data dengan wawancara adalah sebagai berikut a) menyusun kaidah wawancara tak terstruktur, b) wawancara dilakukan secara terang-terangan antara siswa dan peneliti sebagai pewawancara, c) wawancara dilakukan pada 4 siswa yang sesuai dengan indikator, d) Hasil wawancara dianalisis sehingga didapatkan hal yang berhubungan dengan daya cipta atau kreativitas siswa dalam menulis teks persuasi, e) wawancara dilakukan pada jam istirahat atau saat pembelajaran berakhir suapaya kegiatan pembelalajaran pada mata pelajaran lain tidak terganggu.

d. Dokumentasi

Dokumentasi adalah proses pengumpulan data dengan cara mencari informasi melalui catatan atau dokumen yang dianggap relevan dengan masalah penelitian yang berupa naskah atau foto-foto yang berhubungan dengan masalah penelitian (Rukin, 2019).

e. Teknik Analisis Data

a. Pada penelitian ini teknik analisis data yang digunakan merujuk pada teori Miles and Huberman dalam Yusuf (2014) terdapat tiga analisis data yang terdiri dari reduksi data, penyajian data, dan penarikan kesimpulan.

a. Reduksi data

Reduksi data merupakan proses berfikir yang cepat dalam memerlukan kecerdasan dan keluasan didalam wawasan yang tinggi. Peneliti yang masih baru dalam melakukan kegiatan reduksi data dapat berdiskusi dengan teman yang di pandang ahli. Melalui diskusi, maka wawasan peneliti akan berkembang sangat luas, sehingga peneliti dapat mereduksi data-data dan pengembangan teori yang signifikan.

b. Penyajian data

Penyajian data merupakan proses kumpulan informasi yang tersusun dalam proses penyajian data sehingga data yang disajikan akan mudah dipahami serta dapat merencanakan langkah selanjutnya berdasarkan apa yang sudah dipahami tersebut.

c. Kesimpulan dan verifikasi

Verifikasi merupakan proses penarikan kesimpulan awal dan masih bersifat sementara bila tidak ada bukti-bukti yang mendukung dalam pengumpulan data berikutnya. Namun apabila peneliti melakukan penelitian kembali dan masih ditemukan buktibukti yang jelas maka kesimpulan tersebut merupakan kesimpulan yang bisa dipercaya.

d. Teknik Validasi Data

Validasi data pada penelitian ini menggunakan teknik triangulasi. Triangulasi merupakan pendekatan multimetode yang dilakukan peneliti pada saat melakukan penelitian mengumpulkan dan menganalisis data (kasiyan, 2015). Triangulasi yang digunakan pada penelitian ini adalah triangulasi sumber data dan triangulasi metode. Pada triangulasi sumber data, peneliti membandingkan data hasil tes dan wawancara. 


\section{HASIL DAN PEMBAHASAN}

Mengacu pada struktur menulis teks persuasi yang diungkapkan oleh Kosasih. Struktur teks persuasi yang dibuat oleh siswa kelas VIII MTs. Darussalam Deru, Sumberrejo, Bojonegoro, Indonesia sudah merujuk pada struktur teks persuasi sesuai teori Kosasih dengan benar. Adapun struktur tersebut dapat dijadikan sebagai berikut.

\section{Pengenalan isu pada teks persuasi}

Struktur pertama adalah pengenalan isu. Bentuk pengenalan isu pada teks persuasi yang ditulis siswa adalah sebagai berikut

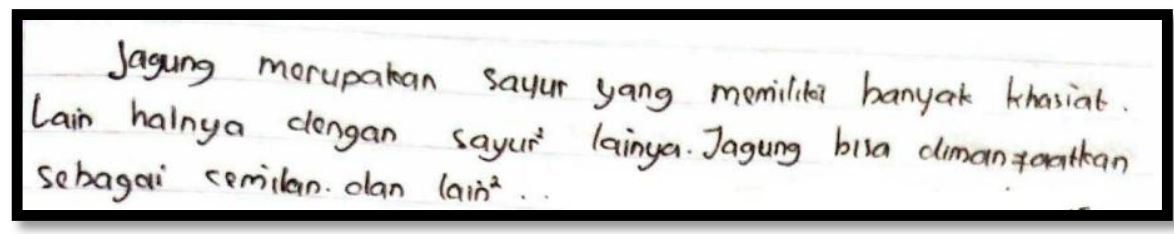

Gambar 2. Pengenalan Isu pada Teks Persuasi

Pada lembar menulis teks persuasi siswa. Siswa membuat pengenalan isu dengan mendeskripsikan jagung sebagai bahan utama snack happytoss. Isi pengenalan isu berisi tentang pembicaraan masalah yang menjadi dasar tulisan. Berdasarkan teks yang ditulis siswa, kita mengetahui siswa mampu membuat pengenalan isu sesuai dengan kaidah teks persuasi. Saat peneliti bertanya, mengapa dia menulis seperti itu, dia menjelaskan bahwa dia pernah melihat iklan di televisi. Hal ini bisa dilihat dari kutipan wawancara berikut.

P : :Apakah kamu sudah memahami struktur menulis teks persuasi?"

S1 : "Sudah, Bu!"

P : :Kamu sudah paham konsep pengenalan isu pada teks persuasi?"

S1 : "Sudah, Bu!"

P : : "Mengapa saudara membuat pengenalan isu teks persuasi demikian?"

S1 : "Karena saya pernah melihat iklan di televisi. Sehingga saya membuat teks persuasi seperti itu".

Pada bagian pengenalan isu teks persuasi. Siswa menulis bagian pengenalan isu berdasarkan isi pengenalan isu yang berisi tentang pembicaraan masalah yang menjadi dasar tulisan. Ide pengenalan isu ini berasal dari iklan yang pernah dia lilihat di televisi. Pengenalan isu merupakan penyampaian pembicaraan masalah tentang dasar tulisan (Kosasih, 2017)

\section{Rangkaian argument pada teks persuasi}

Struktur kedua adalah rangkaian argumen. Bentuk rangkaian argumen yang ditulis siswa pada teks persuasi adalah sebagai berikut.

Mayoritas makunan ringan saat ini banyak mengandung
bahan-bahan kimia. tal tersebul dapat membahayakan
bagi kesehatan yang mengton sumsinya. Makanan
ringan seperti jetz merupakan matanan ringan yelng
aman dikonsumsi karena mengunakan
bahan yang tidat berbahaya bagi fubuh manusea.

Gambar 3. Rangkaian Argumen pada Teks Persuasi

Pada lembar tes menulis teks persuasi ini. Siswa membuat rangkaian argumen dengan mengungkapkan pendapat mengenai makanan ringan. Siswa membandingkan makanan yang mengandung bahan kimia dan tidak mengandung bahan kimia. Pada bagian rangkaian argumen, siswa sudah mampu 
membuat teks persuasi dengan benar. Peneliti mewawancarai siswa mengapa menulis seperti itu, dia mengatakan bahwa dia sering melihat bungkus makanan ringan yang mengandung bahan-bahan kimia yang berbahaya bagi tubuh manusia.

Hal ini dapat dilihat dari wawancara berikut.

P : : "Apakah kamu sudah memahami struktur teks persuasi?"

S2 : "Sudah, Bu"

P $\quad$ : "Mengapa kamu menulis teks persuasi pada bagian rangkaian argument seperti itu?

S2 : "Karena saya sering melihat bungkus makanan ringan yang mengandung bahanbahan kimia yang berbahaya bagi tubuh manusia."

Pada bagian rangkaian argumen teks persuasi. Siswa mampu menulis dengan baik. Bagian rangkaian argumen yang ditulis siswa dengan membandingkan makanan yang mengandung bahan kimia dan tidak mengandung bahan kimia. Ide pengenalan isu ini berasal dari dia sering melihat bungkus makanan ringan yang mengandung bahan-bahan kimia yang berbahaya bagi tubuh manusia. Rangkaian argumen merupakan pendapat penulis terkait isu yang diungkapkan sebelumnya (Kemendikbud, 2017).

\section{Pernyataan ajakan pada teks persuasi}

Struktur ketiga adalah pernyataan ajakan. Bentuk pernyataan ajakan yang ditulis siswa pada teks persuasi adalah sebagai berikut

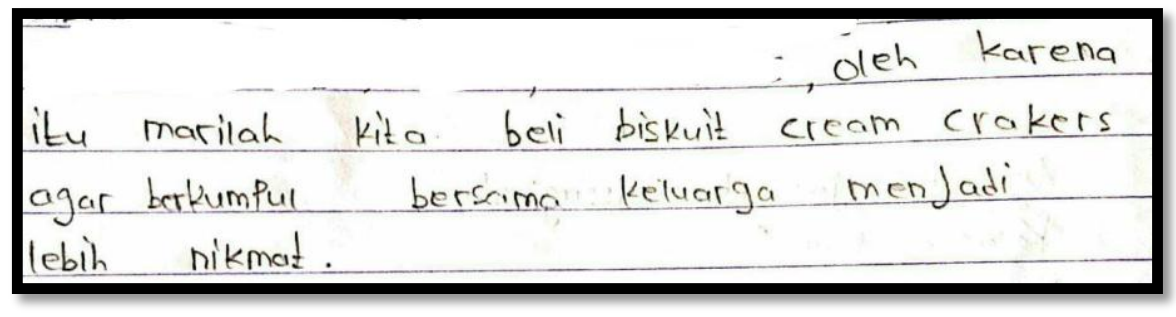

Gambar 4. Pernyataan Ajakan pada Teks Persuasi

Pada lembar tes menulis teks persuasi, siswa menulis bagian pernyataan ajakan dengan menulis kalimat pernyataan ajakan supaya pembaca tertarik untuk membeli. Peneliti mewawancarai siswa mengapa siswa menulis seperti ini, dia menjawab pernah melihat kalimat ajakan pada kemasan makanan. Hal ini dapat dilihat pada kutipan wawancara berikut.

P : : "Mengapa kamu menulis bagian pernyataan ajakan seperti ini?"

S3 : "Karena saya pernah melihat kalimat ajakan pada kemasan makanan"

Pada bagian pernyataan ajakan teks persuasi. Siswa menulis bagian pernyataan ajakan dengan menulis kalimat pernyataan ajakan supaya pembaca tertarik untuk membeli.. Bentuk pernyataan ajakan dibuktikan dengan adanya kalimat ajakan untuk membeli biskuit cream creakers. Pernyataan ajakan tidak hanya terdapat di dinding tetapi juga terdapat di kemasan kudapan (Djuandi, 2016).

\section{Penegasan kembali pada teks persuasi}

Struktur keempat adalah penegasan kembali. Bentuk penegasan kembali yang ditulis siswa pada teks persuasi adalah sebagai berikut.

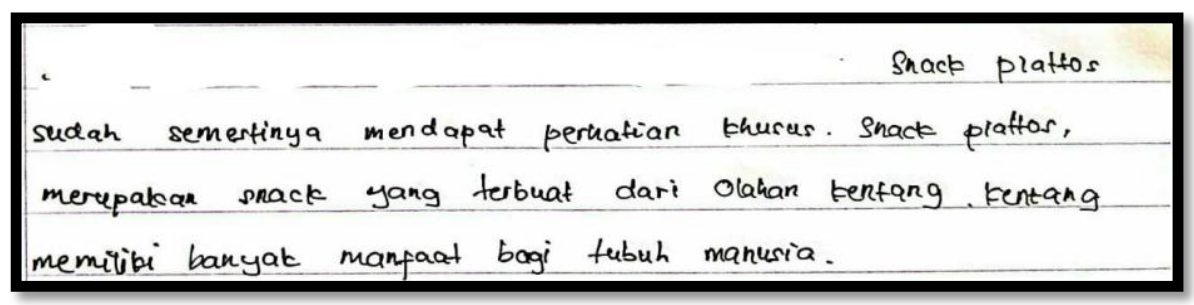

Gambar 5. Pernyataan Penegasan Kembali pada Teks Persuasi 
Pada lembar tes menulis teks persuasi, siswa menulis bagian penegasan kembali dengan menulis teks yang menegaskan tentang pernyataan sebelumnya. Saat peneliti melakukan wawancara dengan siswa, mengapa dia menulis seperti itu, dia menjawab berdasarkan ide saya sendiri. Hal tersebut dapat dilihat dari kutipan wawancara sebagai berikut.

P : "Mengapa kamu menulis teks persuasi bagian penegasan kembali seperti ini?"

S4: "Saya menulis teks persuasi pada bagian penegasan kembali berdasarkan ide saya sendiri".

Pada bagian penegasan kembali teks persuasi. Siswa mampu menulis dengan baik. Bagian penegasan kembali yang ditulis siswa menegaskan tentang pernyataan sebelumnya. Bentuk penegasan kembali dibuktikan dengan kalimat yang menjelaskan tentang manfaat kentang. Penegasan kembali menurut Arbi, Thahar \& Emidar (2018) merupakan penegasan ulang teks yang berisi pernyataan sebelumnya.

Kemampuan siswa kelas VIII MTs. Darussalam Deru, Sumberrejo, Bojonegoro, Indonesia dalam menulis teks persuasi berbantuan kemasan kudapan sesuai dengan struktur teks persuasi menunjukkan bahwa pembelajaran discovery learning berbantuan media kemasan kudapan sangat cocok diterapkan pada kompetensi dasar 4.14. Penerapan pembelajaran discovery learning berbantuan media kemasan kudapan memberikan pembaruan dalam proses belajar pembelajaran serta siswa terdorong untuk mempelajari materi pembelajaran.

\section{KESIMPULAN}

Bentuk teks persuasi yang ditulis oleh siswa kelas VIII MTs. Darussalam Deru, Sumberrejo, Bojonegoro, Indonesia pada pembelajaran dengan menerapkan metode discovery learning telah mengacu pada struktur teks persuasi sesuai dengan teori Kosasih dengan baik. Pada bagian pengenalan isu, siswa menulis pengenalan isu berdasarkan iklan yang pernah dia lihat di televisi. Pada bagian rangkaian argumen, siswa menulis rangkaian argumen yang menggambarkan bagian rangkaian argumen yang ditulis siswa dengan membandingkan makanan yang mengandung bahan kimia dan tidak mengandung bahan kimia. Pada bagian pernyataan ajakan, siswa menulis bagian pernyataan ajakan dengan menulis kalimat pernyataan ajakan supaya pembaca tertarik untuk membeli. Pada bagian penegasan kembali, siswa menulis penegasan kembali berdasarkan tentang pernyataan sebelumnya.

\section{DAFTAR PUSTAKA}

Arikunto, S. (2006). Prosedur penelitian suatu pendekatan praktik. Jakarta: Rineka cipta Kemendikbud. (2017). Buku siswa bahasa dan sastra Indonesia wahana pengetahuan untuk SMP/MTS Kelas VIII. Jakarta: Kemendikbud.

Kosasih, E. (2017). Bahasa Indonesia SMP/MTs kelas VIII. Jakarta: Kementrian pendidikan dan kebudayaan

Rukin, (2019). Metodologi penelitian kualitatif. Sulawesi selatan: Yayasan ahmar cendekia Indonesia. Sugiyono. (2015). Metode penelitian kuantitatif, kualitatif, dan R\&D. Bandung: Alfabeta.

Sugiyono, (2015). Memahami penelitian kualitatif. Bandung: Alfabeta.

Tarigan, G. H. (2008). Menulis, sebagai suatu keterampilan berbahasa. Bandung: Angkasa Bandung Yusuf, M. (2017). Metode penelitian: kuantitatif, kualitatif \& penelitian gabungan. Jakarta: Kencana.

\section{Sumber Jurnal}

Amalia, F., Syahrul, R., \& Arief, E. (2018). Pengaruh model discovery learning berbantuan media audiovisual terhadap keterampilan menulis teks eksposisi siswa kelas VIII SMP Negeri 31 Padang. jurnal pendidikan bahasa dan sastra Indonesia, 1(7), 125-132. Retrieved from. http://103.216.87.80/ index.php/pbs/article /view/9551 
Arbi, M. D. P., Thahar, H. E., \& Emidar. (2018). Kontribusi keterampilan membaca pemahaman terhadap keterampilan menulis teks eksposisi siswa kelas VIII SMP negeri 25 Padang. jurnal pendidikan bahasa Indonesia,7(3), 137-143. Retrieved from http://ejournal.unp.ac.id/index.php/pbs/article/view/100723

Cahyaningsih, S. dan Wikanengsih. (2019). Upaya peningkatan menulis teks persuasi menggunakan metode STAD pada siswa SMP. jurnal pendidikan bahasa dan sastra Indonesia, 2(2), 209-214. Retrieved from. https://journal.ikipsiliwangi. ac.id/index .php/parole/article/view/2671/pdf

Djuandi, D. (2016). Pengaruh pembelajaran berbasis masalah terhadap sikap siswa pada lingkungan (studi eksperimen quasi pada mata pembelajaran geografi di SMA Negeri 1 Purwadadi). jurnal pendidikan geografi, 16(1), 24-33. Retrieved from https://ejournal.upi.edu/index.php/gea/article/view/3465

Fauzi, A. R., Zainuddin, \& Atok, R. A. (2017). Penguatan karakter rasa ingin tahu dan peduli sosial melalui discovery learning. jurnal teori dan praksis pembelajaran IPS, 2(2), 27-36. Retrieved from. http://journal2.um.ac.id/index.php/itppips/article/view /2500

Hasanudin, C. (2016). Pembelajaran Membaca Permulaan dengan Menggunakan Media Aplikasi Bamboomedia Bmgames Apps Pintar Membaca sebagai Upaya Pembentukan Karakter Siswa Sd Menghadapi MEA. Pedagogia: Jurnal Pendidikan, 5(1), 1-12. Doi http://doi.org/10.21070/pedagogia.v5i1.84.

Hidayah, R. N., Darmuki, A. \& Hasanudin, C. (2019). Peningkatan keterampilan menulis puisi dengan menggunakan metode quantum learning dan media video pada siswa kelas X IPA I SMA Negeri 2 Blora tahun ajaran 2018/2019. Jurnal linguistik, sastra, dan pendidikan, 4(1), 309-320.

Retrieved from http://ejournal .unwmataram.ac.id/trendi/article/view/152

Kasiyan, (2015). Kesalahan implementasi teknik triangulasi pada uji validitas data skripsi mahasiswa jurusan pendidikan seni rupa FBS UNY. jurnal imaji, 13(1), 1-13. Retrieved from https://journal.uny.ac.id/ index.php/imaji/ article/ download/4044/3498

Mardhiyah, N. (2019). Peningkatan proses dan hasil belajar bahasa Indonesia materi teks persuasif dengan pendekatan inkuiri pada siswa kelas VIII-D SMP Negeri 2 Girimarto tahun ajaran 2018/2019. jurnal penelitian pendidikan, 3(3), 279-283. Retrieved from. https://scholar.google.co.id / scholar?hl=id\&as $\mathrm{sdt}=0,5 \& \mathrm{q}=$ jurnal+PENINGKataN+PrOsEs+DaN+HasIL+BELaJar+BaHasa+INDONEsla+MatErI+tEKsPErsUasIf+ DENGaN+PENDEKata

Nurfaedah. (2019). Keefektifan media audio visual dalam meningkatkan kompetensi siswa sekolah menengah pertama dalam menulis puisi. Indonesian journal of instructional media and mode, 1(1), 36-44. Retrieved from. http://journal.univetbantara. ac.id/index .php/ijimm Larticle/view $/ 316$

Nurmalasari. (2020). Kemampuan menulis paragraf persuasu siswa kelas VIII MTSN 4 Palu. jurnal bahasa dan sastra, 5(2), 60-72. Retrieved from. http://jurnal.untad.ac.id/jurnal/ index.php/BDS/article/view/12717

Retnowati, R., Suharyati, H., Manurung, R.T., Maknun, D., Armariena, D.N., Hetilaniar, H., Hasanudin, C., Murniviyanti, L., Anwar, S., Setyorini, R. (2018). The effect of environmental teaching method and the level of natural intelligence on the environmental view of the students behavior. Journal of Physics: Conference Series, 1114(1), 1-7. Doi https://doi.org/10.1088/17426596/1114/1/012104.

Sari, R. A. \& Rachmawati, Y. (2019). Analisis pengaruh parsial, kemasan, warna, rasa dan pengetahuan gizi terhadap keputusan pembelian produk makanan pada siswa SD. jurnal teknovasi, 6(2), 27-34. Retrieved from http://ejurnal.plm.ac.id/index.php /Teknovasi/article/view/344

Yandis, S. M., Pujilestari, C., \& Wuryani, W. (2019). Analisis penggunaan kata ajakan dalam menulis teks persuasi pada siswa kelas SMP. jurnal pendidikan bahasa dan sastra Indonesia, 2(3), 385390. Retrieved from. https://journal.ikipsiliwangi.ac.id/index. Php/parole/article/view/2798. 